\title{
UMA CULTURA DA VIOLÊNCIA NA CIDADE? rupturas, estetizações e reordenações
}

\author{
Rosamaria luiza de Melo Rocha \\ Membro-fundador do Centro de Estudos e Pesquisas em Novas Tecnologias, Comunicação e Cultura - ECA/USP
}

A proposta deste artigo é abordar aspectos da relação entre cultura e violência nas metrópoles contemporâneas, ${ }^{1}$ investigando, como pista analítica central, a definição do que seria uma "linguagem da violência". Postula-se que tal linguagem estabelece liames com manifestações sociocorporais específicas, bem como interações dialógicas com o universo mediático, evidenciando a consecução de práticas originais de sensibilidade e sociabilidade. Busca-se, ainda, identificar possíveis canais de ruptura com o ciclo da violência como ato social que estariam presentes nesta linguagem.

Para atingir tal objetivo analítico, parte-se de um mapeamento sucinto que nos permita lançar alguns parâmetros para a localização da violência no campo da cultura e, a seguir, para que se compreenda sobre que bases seria possível, em nosso entender, refletir-se sobre a estetização da violência, seja do ponto de vista de suas interações com a tessitura social, seja de sua interseção com o próprio estatuto das imagens.

Assim, inicialmente perguntamos: em que termos se pode falar da constituição de uma "cultura da violência" nas cidades? Como a experimentação fragmentária da violência - simbólica e real - atua e interage com manifestações culturais contemporâneas? Defendemos que estudos localizados neste campo de indagação não devem ceder aos atalhos enganosos que conduzem à reafirmação de um mito, de todo circulante, mas sim revelar o que há de humano na sua construção e na rede de crenças e credibilidades que incessantemente o movem. Tais investigações, ao que nos parece, funcionam como visões em mosaico, religando informações múl- tiplas, com o olhar e a reflexão, ao contexto a que pertencem. Selecionamos, com este fim, interpretações que nos parecem sugestivas e, a seguir, emprestamos, de outras, noções que consideramos pertinentes para embasar o enfoque específico deste artigo.

\section{VIOLÊNCIA E CULTURA: "SOMATIZANDO" IDENTIDADES?}

"Cultura' é uma palavra imprecisa", comenta Peter Burke, antes de oferecer a seguinte definição, que adota em seus estudos: "um sistema de significados, atitudes e valores partilhados e as formas simbólicas (apresentações, objetos artesanais) em que eles são expressos ou encarnados" (Burke, 1989:15).

Ao se falar, pois, em "cultura da violência", supõe-se que, no lugar simbólico preenchido por referências externas ao indivíduo e, principalmente, na trama compartilhada de significados, valores e atitudes, aí se encontraria a violência. Teríamos então de imaginar uma visão suficientemente coesa - e, portanto, sujeita a uma larga margem de simplificação - do mundo que é objeto de percepção e experiência e da malha cultural daí resultante, encontrando-se, como parâmetro para a interação social e simbólica, a violência enquanto "agregador" comum. Não acreditamos estar suficientemente clara esta alternativa. Vejamos em que nos pode ajudar a forma como esta problemática é conduzida por alguns pesquisadores.

Tomando o exemplo de Freire Costa (1993), a "cultura da violência", na nova feição assumida no Brasil, é 
aquela que, "no vácuo da lei", "segue regras próprias", tornando a violência um padrão de referência familiar, corriqueiro, cotidiano: "A violência torna-se um item obrigatório na visão de mundo que nos é transmitida. Cria a convicção tácita de que o crime e a brutalidade são inevitáveis. (...) A imoralidade da cultura da violência consiste justamente na disseminação de sistemas morais particularizados e irredutíveis a ideais comuns, condição prévia para que qualquer atitude criminosa possa ser justificada e legítima. (...) Em segundo lugar, a cultura da violência, valorizando a utilização da força, constrói uma nova hierarquia moral. O universo social simplifica-se monstruosamente entre fortes e fracos (Freire Costa, 1993:84-5).

Um paradoxo se evidencia ao se comparar a definição de Freire Costa com o que propõe Burke. Como se pode falar em uma "cultura da violência" se na realidade se está diante de um quadro de cisão de preceitos coletivamente partilhados? Nota-se que o próprio Freire Costa consegue equacionar esta charada, procedendo à seguinte distinção: na banalização dos delitos e na amplificação dos riscos, floresce o medo social, "o pânico com características fóbicas", capaz, por seu turno, de dar à palavra violência o status de "entidade". É exatamente esta zona amorfa o "bem" compartilhado: "O hábito que criamos de falar da Violência com ' $V$ ' maiúsculo é uma defesa contra o medo. (...) a fantasia da violência paralisa nosso pensamento e nossas ações (...) a violência, nesse caso, é apenas um fetiche, uma figura de linguagem, cuja matéria é nosso medo" (Freire Costa, 1993:86-7).

Em seu estudo etnográfico junto a meninos e adolescentes vivendo nas ruas da cidade do Rio, Silva e Milito (1995) também se utilizam de noções relacionais de cultura, ambas a atestar a ruptura do coletivo, a criação de uma "ordem" tensa, potencialmente explosiva: "É dissonante o som da voz que protesta em nome do menino, sempre abafada pelo coro agressivo das ameaças. (...) Quando protestam (...), o protesto vai-se refreando progressivamente, na contenção dos gestos, no paulatino racionamento das expressões verbais (...). Enfim, chamaríamos a essa disposição genérica, não quantificada, ou mesmo quantificável, de uma "cultura da evitação", a produzir freneticamente objetos, disposições e atitudes que afastem os personagens da rua, indesejáveis, grosseiros e perigosos. Por outro lado, em seus contatos com a difusa sociedade dos aquinhoados, esses personagens marginalizados (...) estão permanentemente a negacear, a se contradizer, a modular seu comportamento num sentido táti- co para auferir vantagens contingentes. É o que chamaríamos, por seu turno, de "cultura da evasiva"' (Silva e Milito, 1995:35-8).

Vamos agora considerar que se possa falar de "cultura" como parte de um "processo de incorporação de estruturas sociais que faz com que o indivíduo se ligue a tal mundo social, que o 'conheça', mas com um conhecimento que não possui nada de intelectual", resultando, esta incorporação, em estratégias de "aquisição de competências sócio-corporais tácitas, que são como este sexto sentido que nos guia em nosso mundo vivido" (Wacquant, 1996:215). ${ }^{2}$

O "saber somático" a que se refere Wacquant pode ser transposto para a análise do que seria uma "cultura da violência". Afinal, como por sua vez lembra Wittner (1992), "a imagem da violência cola à pele", "ensinando aos jovens a linguagem que eles têm de utilizar para existir". A violência como modo de expressão, continua a autora, está de par com a mediatização, aparecendo, para membros de grupos excluídos, como uma das formas mais imediatas de obter atenção. ${ }^{3}$

Em outros de seus desdobramentos, a violência pode ainda se associar ao prazer, ao consumo e à criação de identidade, construindo, na interseção com o universo dos media e com aquele da criminalidade, a glória intensa e fugaz detectada por Ventura (1994), a busca e a utilização de signos de vitória e projeção. $\mathrm{O}$ fascínio da visibilidade e do reconhecimento - ancorado no estrelato mediático ou na força bruta da ação criminal - cria um inusitado barômetro do sucesso, material e simbólico: ter e poder (poder ter, poder fazer, poder falar, poder aparecer). ${ }^{4}$

É complexa a avaliação das inúmeras ramificações da adoção por uma dada sociedade ou grupo social da violência (ou da Violência, como quer Freire Costa) como parte constitutiva de seu elenco de artefatos culturais. Mas, tendo em vista as abordagens enumeradas, podemos inferir que, se há uma conformação compartilhada que nos permite falar de uma "cultura da violência" em uma sociedade intensamente fragmentada, ela se processa em uma dinâmica, semelhante àquela notada por Michel De Certeau, de oscilação entre singularidade e pluralidade: "De um lado, ela [a cultura] é aquilo que 'permanece'; do outro, aquilo que se inventa. Há, por um lado, as lentidões, as latências, os atrasos que se acumulam na espessura das mentalidades, certezas e ritualizações sociais, via opaca, inflexível, dissimulada nos gestos cotidianos, ao mesmo tempo os mais atuais e milenares. Por outro lado, as irrupções, os desvios (...). A cultura no singular impõe 
sempre a lei de um poder. (...) A cultura no plural exige incessantemente uma luta" (De Certeau, 1995:239242).

Porém, nas culturas da violência, a inventividade, o papel criador do inesperado, já não parecem nos trazer alento. Microscopicamente, o que por vezes volta a germinar é o endurecimento da exclusão, o rosto embrutecido de um tempo de intensidade e apatia. Mas talvez não sejam relativamente poucos os que possam, como o rapper americano Coolio, declarar: "Minha mãe me criou muito bem. Mas você cresce no gueto, e pode acreditar que tudo que você já ouviu falar sobre lá é verdade. Então, quando eu estava no colegial, caí no caminho errado. Drogas, roubo, briga. Eu assaltava casas. As coisas que eu vi e fiz, era para estar até hoje na cadeia ou morto. Mas acordei para o caminho certo, pela música (...). Conheci algumas pessoas que faziam rap e resolvi tentar por mim mesmo. (...) Não é o rap que faz o mundo ser ruim, é o mundo que faz o mundo ser ruim" (Entrevista a Camilo Rocha, Folha de S.Paulo, 01/05/97).

Em suma, o mal-estar que procede da associação entre as idéias de cultura e de violência levam-nos à seguinte proposição. Pelos atalhos da linguagem, vislumbramos como definição possível exatamente aquela de "linguagem da violência", que, como toda linguagem, pode ter uma "função poética", o germe de uma poiesis das reminiscências. Rappers como Coolio ou, para nos aproximarmos mais diretamente de nosso país, como os integrantes do "Câmbio Negro", do "Pavilhão 9", incorporam, em suas canções, o duplo movimento de retomar a palavra e, no campo da cultura, de se "descolar" da engrenagem da violência como ato social, ao menos no que toca a uma participação ativa nesta ação. Aqui, o descolamento não equivale a uma negação da violência vivida, sequer da violência vista. Representada (musicalmente, imageticamente), ela não é esquecida: é rememorada mas, igualmente, abstraída. Estetizada, comunica-se como choque mas, igualmente, dá-se a ver. E, àqueles que a produzem, possibilita uma interessante inversão da sedução voyeurística do "ver-se sendo visto".

Neste caso, a linguagem da violência não precisa ser surpreendida ou contida como prática delitiva: ela faz do delito o suporte lingüístico e imagético que a estrutura apenas em sua origem. Pela via poética, a violência, como linguagem, pode prescindir da violência como ato social, como prática cotidianamente encampada. Talvez, em um caso raro, a violência possa aqui ser vivida, sem motivo para culpabilizações, como imagem. Imagem, é claro, alimentada de "reais" e "imaginados", mas retrabalhada ou reconduzida a um novo ciclo (discursivo, simbólico, criativo) que não o da eterna repetição da violência.

A linguagem da violência, por esta via poética que não elimina a estética do choque, pode funcionar como uma perlaboração produtiva da violência real, um revisitar e uma reelaboração de sítios simbólicos e memoriográficos marcados pela obliteração social traumática. Um exemplo especialmente sugestivo de tal situação vem do grupo paulistano de rap "Racionais MC's". Em seu mais recente disco, "Sobrevivendo no Inferno", agora cultuado, os rappers compõem uma música - "Diário de um Detento" - e, posteriormente, produzem um videoclipe, baseados nos fragmentos do diário de um dos sobreviventes do massacre do Carandiru. As reminiscências de um circo de horror vira hit nacional. E, assim, o esquecido, o imageticamente, simbolicamente ocultado, reinscreve-se no imaginário ou, mais ainda, na imagerie ${ }^{5}$ de vários setores do país.

Acreditar nesta possibilidade não significa, contudo, uma licença ingênua, um sorridente apaziguar de um quadro que é tenso e conflituoso. Recorrendo ao polêmico René Girard, nota-se, ao se compor uma das faces obscuras da "linguagem da violência", as estruturas miméticas da rivalidade. Considerar, portanto, que esta linguagem nem sempre é um sistema fechado, absoluto, não permite que se feche os olhos para o teor dos espaços outros com os quais ela se põe em contato.

Nos gestos de agressão cega, de violência pela violência, referentes externos são fatalmente desconsiderados, criando um dialeto endurecido onde o "fazer a coisa certa" submete-se a infindáveis táticas de recuo personalista. Nos caminhos que por sua vez unem o fato ao mito, a consumação da violência à fobia, a agressão à defesa, cruzam-se a percepção de um mundo externo excessivamente ameaçador e a sua intencional obliteração, entrave dispensável que se elimina, com finalidades diversas, dos shoppings aos territórios dominados pela criminalidade organizada. Uma "linguagem da violência"? É possível... Mas comportando, no seu modo de constituição e expressão, um constante oscilar entre cool e hard.

\section{AUTONOMIZAÇÃO DA VIOLÊNCIA E ESTRATÉGIAS IDENTITÁRIAS: VISIBILIDADE E MEDIATIZAÇÃO}

A autonomização da violência, sua experimentação como potência estranha e misteriosa, interfere de modo 
por vezes devastador em nossos discursos e comportamentos. Se sua leitura ou decodificação consiste em tarefa um tanto inglória para estudiosos da cultura e da sociedade, o seu impacto mudo e difuso pode ser visto e vivenciado, sem maior esforço, em nossa realidade física e temporal. Com a crise das metanarrativas ela se apresenta como uma forma privilegiada de comunicação, de organização de interesses e resolução sumária de conflitos, como parte constitutiva do dia-a-dia.

Segundo o relato de Zaluar (1994), que depura, aos olhos do leitor, uma miríade de nuances da percepção e da prática da violência em um conjunto habitacional da periferia carioca, ${ }^{6}$ os jovens, por motivos prosaicos, vêem-se diante de "uma engrenagem que eles não controlam (...) a engrenagem das quadrilhas de traficantes de tóxicos e da polícia, que toma cada vez mais a feição de crime organizado. A razão inicial pode ser o roubo ou humilhação sofridos por um jovem a caminho do trabalho e que tem a desventura de topar com um bandido de outro território. Ou uma briga por causa de mulher" (Zaluar, 1994:21-2).

Preocupando-se com o efeito devastador do crime organizado nas práticas sociocorporais e na identidade destes jovens, Zaluar detecta, nas quadrilhas, uma poderosa função de socialização, cuja coesão e perenidade são garantidas pelo "uso manifesto e constante da violência" (Zaluar, 1994:77). O caráter ordenador da violência revela-se, ainda, na sua constituição como base interpretativa dos agentes, "pensada em torno do poder advindo da posse ou uso da arma de fogo" (1994:76).

Discutindo a violência a partir da tríade violência/criminalidade/narcotráfico, Machado da Silva (1994) é esclarecedor ao enfocá-la não mais como reação a uma ordem estabelecida ou como "desvio" do sistema. ${ }^{7}$ Segundo afirma, a violência toma parte de um processo de "desconcentração", portando uma lógica própria, um funcionamento autônomo, endógeno: "a organização privada da violência nas cidades brasileiras atuais não é nem desviante, como pensa a explicação dominante, nem se constitui como um conflito de legitimidade (...) entre grupos ou categorias politicamente orientadas; ela se constitui como um processo de legitimação de novas regras de convivência associadas a conteúdos de relações sociais também originais, instituindo um novo padrão de sociabilidade" (Machado da Silva, 1994:162).

Acreditamos que a inovadora perspectiva adotada por Machado da Silva corrobora a noção de autonomização, lançando, ainda, nova luz às idéias correntes de deslegitimação e desconcentração e ao nexo causal entre estes processos e a dinâmica da violência contemporânea: "pelo menos em princípio é preciso admitir que, mesmo sendo produzido num contexto (...) de crise 'interna', o processo de organização dos criminosos comuns pode criar uma lógica própria e originar efeitos divergentes em relação aos conflitos que foram sua condição de possibilidade. (...) As organizações criminosas atuais, embora sejam empreendimentos econômicos altamente lucrativos (...) não são empresas, no sentido de comporem-se de uma hierarquia orientada para fins coletivos. (...) Pouco se sabe sobre a natureza desse processo, mas talvez não seja absurdo pensálo como assumindo a forma de algo como uma 'estratégia militar personalizada' (...) através da criminalidade organizada, a violência privada já se consolidou como uma forma autônoma de sociabilidade dotada de uma dinâmica independente" (Machado da Silva, 1994:163-167).

Colocadas em contraplano, as visões de Machado da Silva e Zaluar levam-nos à seguinte questão: o modus operandi da criminalidade - base dos temores de alguns, base de ação para outros, fundamento decisivo da consciência e da conceituação da violência contemporânea - não pode, de fato, ser estritamente definido como poder ou, na definição contestada por Machado da Silva e corriqueira no senso comum, sequer como poder paralelo. Ele se encaixaria mais adequadamente na definição de "força", aquela que desconhece um sentido dialógico, espraiando, para além de seu território, o monólogo obsessivo do "mais forte". 8

Mas a violência como vetor identitário não é, necessariamente, criminalizável, sequer se presta exclusivamente à consecução de estratégias que permitem eleger e lidar com "novos bárbaros". Ela instaura um regime - visual e social - extremamente flexível, permeável às mais diversas comutações, viral, obsceno. Como já notado, ela organiza sociabilidades e funda a legitimidade interna de grupos sociais, como no caso da criminalidade organizada. É canal desejado de interação, notando-se o recurso a meios simbólicos para expressar a violência e a agressividade: é a externalidade da estética punk, é o enfrentamento ritualizado das galeras funkeiras, é a linguagem do gangsta rap. ${ }^{9}$

Diz respeito, ainda, à mobilização da sensibilidade e ao desejo de visibilização que envolve a forma de aparecimento e organização de fenômenos coletivos de violência - linchamentos, conflitos entre torcedores, grupos de carecas e neonazistas - levados a cabo com toques rituais, coreográficos e com uma presença peculiar no espaço público e mediático. A ficcionalização da violência não está apenas nas salas de cinema ou nas telas de tevê. Ela mora ao lado. 
Tal estetização não possui, em si, um caráter estritamente desviante. Portadora de uma estética própria é, por exemplo, a coreografia presente em parte das ações policiais. Na invasão em massa, na excitação incontrolável que resultou no trágico massacre do Carandiru, não seria correto postular que, ao lado de uma autonomização da violência, havia uma mobilização intensa de sensibilidades?

Estas manifestações violentas aproximam-se - em recortes específicos - das noções de "violência auto-referente" e "violência estetizada". Há uma tendência autoexplicativa nestes fenômenos vividos aos moldes de uma arte pela arte; a violência pela violência dispensa relatos legitimadores a ela exteriores. Ela é sua própria justificativa, fala por si, passa a ser um fim em si mesma, explicase em seu acontecer fenomênico e endógeno.

De que modo esta zona de nebulosidade, de confusão, extrapola o plano conceitual, o plano das palavras e dos temores que geram discursos, e se instala no formato de nossas casas, na feição de nossos bairros, na estruturação de nossas cidades? Como a mixagem entre suposto, possível e acontecido ganha um corpo suficientemente coeso de modo a possibilitar a sensibilização de sua imagem e seu posterior registro no filme urbano? Como interfere, igualmente, em nosso modo de vestir e andar, nas nossas relações de sociabilidade, em nossas formas de agrupamento e comportamento? Quando é que esta violência fragmentária deixa de representar uma ameaça contra a qual se deva reagir para se tornar parte de uma brincadeira da qual se deseja participar?

Jogando neste meio de campo, está o vizinho da mesa ao lado, está o jovem executivo que tenta matar, com as próprias mãos, o homem que acabara de roubar o tocafitas de seu carro, está o grupo de taxistas e "donas-decasa" que se mobilizam para linchar supostos assaltantes, está o office-boy que se envolve ferrenhamente nas brigas em campos de futebol, estão os participantes de "arrastões" cujo principal objetivo é "arrepiar os bacanas", está também o jovem de classe média que rouba para "zonear", para viver perigosamente, estão os policiais que, como se estivessem se divertindo, matam, extorquem e torturam no "exercício do poder", estão os "carecas" que espancam homossexuais e nordestinos, dizimando por vezes não um "outro" mas o seu próprio reflexo rejeitado, expurgando violentamente o peso indesejável de uma "herança" involuntariamente adquirida.

As formas de violência marcadas por um caráter anômalo e/ou estetizado permitem, ainda, que se façam algumas associações. Vamos localizar dois pontos nodais deste argumento: o papel decisivo dos media na estruturação de nossas vidas; e o papel decisivo da violência autoreferente na organização de relações de comunicação e de sociabilidade. Acreditamos que estes vetores encontram-se, atualmente, em um estado de contigüidade ou simbiose.

O vivenciar efetivo da violência pelos homens, como participantes ativos ou passivos, não é algo indispensável à elaboração deste ou daquele discurso, tenha ele aspirações analíticas ou expresse a linguagem que corre nas ruas, o senso comum. Mas são por demais intrigantes o caráter e a utilização que se faz desta "lente subjetiva": ora como lente de aumento, ora como caleidoscópio.

Não seremos os primeiros a afirmar que há um "descolamento" - ou ao menos uma vinculação nebulosa entre as idéias e opiniões sobre o caráter e dimensão atual da violência e seu acontecer objetiva ou empiricamente aferível. A consideração deste gap é o ponto de partida adotado, por sua vez, em diversos estudos contemporâneos de análise das relações entre violência, cultura e os media. $^{10}$

Partimos do pressuposto de que à existência efetiva de manifestações violentas no espaço/tempo das grandes cidades não corresponde uma elaboração mental e conceitual do fenômeno imediatamente similar a aspectos concretos ou estatisticamente quantificáveis do mesmo, fato reforçado pela ampla gama de manifestações que têm se encaixado na complexa definição da violência nas sociedades deste final de século.

Os discursos, a percepção e a prática da violência estão hoje irreversivelmente marcados por um novo regime de organização e visibilidade: violência pela violência, violência em tempo real, violência universalizada, violência estetizada. A violência, em nosso cotidiano, caracteriza-se progressivamente por assumir um caráter polimorfo, tanto em termos de sua percepção quanto de sua realização.

Estas imagens e "representações", ainda que polissêmicas e difusas, estão hiperpresentes e são uma moeda de troca comum na vida cotidiana, condensando-se, em alguns momentos, em manifestações violentas visibilizadas, autoreferentes, no registro destas cenas e incorporando-se, de forma indireta, na ordenação visual, espacial e temporal das cidades. A violência remete, neste caso, a vestígios de uma "cena" anterior, suposta ou efetiva, seja como defesa contra a ameaça da violência, seja para facilitar a sua prática.

No caso da violência veiculada através dos media, as informações são reprocessadas, transformadas em ima- 
gens/sons peculiares. A capacidade de reverberação da televisão - amplificando e visibilizando os relatos cotidianos, preenchendo de imagens o que no rádio era apenas som, dando movimento às fotografias e voz ao texto de jornais e revistas - cria um certo continuиm mediático. Falar dos media é falar desta lógica comum, circular e tautológica, irradiada pela penetração ostensiva da televisão em milhares de domicílios. Apenas os puristas, para usar um termo suave, se chocam com a presença de parabólicas em algumas favelas.

A velocidade e a pluralidade da linguagem televisiva tornam as imagens/sons de violência mais pulsantes, mais urgentes, mais presentes. Se este estado de televisualização constante da violência pode ocasionar um desgaste, um arrefecimento das sensibilidades, não tem eliminado a atração, ainda que com altos e baixos, por programas violentos, sejam jornalísticos ou não. Não deixa de ser interessante que, entre estes últimos, os que se pretendem ser ou se consideram os mais próximos da realidade sejam aqueles que mais "ficcionalizam" o registro das cenas, caso mais perene e visível nos atuais herdeiros do "Aqui Agora", mas igualmente presente nos flagrantes, nas reportagens com câmeras escondidas. Estética da delação que manipula o visível, dando-nos a ver um campo híbrido, no qual o anseio por uma Ética é muitas vezes sobrepujado por um torpe macaquear de denúncias-entretenimento.

Não por acaso, uma das últimas cenas chocantes de violência exibidas nas tevês - o linchamento de assaltantes em Matupá - havia sido realizada por um cinegrafista amador. Algo similar aconteceu com o paradigmático flagrante de barbarismo policial em Diadema, exibido em abril de 1997 pela Rede Globo, seguida por outras emissoras. Como no filme Na Mira da Morte, ${ }^{11}$ de Peter Bogdanovich, o horror da realidade parecia, em uma questão de segundos, ultrapassar a ficção.

Tornar a "violência pura" ficção pareceria, até há poucos anos, uma irrealidade para boa parte das produções jornalísticas. Agora, a violência assume-se como espetáculo, não mais como espetáculo do real, mas supondo a própria teatralização deste real, um real que já é profundamente performático, estetizado, vivenciado, ainda que de maneira angustiada, como uma grande fábula.

Seguindo uma lógica similar à dos media, o agir violento e alguns dos discursos que o analisam tornam-se tautológicos: as pressões são violentas porque a sociedade é violenta; as pessoas são reativas pela necessidade de se defender contra a violência; cresce a impunidade por- que a sociedade é violenta; a sociedade é violenta porque cresce a impunidade; etc.

Esta mesma condição é passível de ser encontrada em alguns fenômenos de violência, seja ela grupal ou individual. Não é para nós estranha a afirmação da "gratuidade" de determinados atos violentos: pessoas mortas, durante assaltos, sem que tivessem esboçado qualquer reação; jovens que embarcam na criminalidade por diversão; pacatos cidadãos que se "transformam", da noite para o dia, em matadores de aluguel, em assassinos compulsivos.

É interessante notar como esta auto-referência compartilhada interfere ativamente na criação das imagens mentais, das visões sobre a violência. Composta de relatos, de fragmentos de cenas, de ficção e da real experimentação de casos de violência, nesta visão em mosaico o caso individual é projetado para a coletividade: se chegou a acontecer comigo, pode acontecer com todos; se chegou a acontecer com alguém, pode acontecer comigo. Daí para o temor da vitimização, o sentimento generalizado de insegurança e o pânico é apenas um passo. Desta complexa aglutinação algo parece emergir. Agora, a violência, para o bem e para o mal, ou acima deles, é um fator de identidade, mais do que possível, almejado.

Trágica estetização, trágica perpetuação de uma violência discurviva e mediatizada. É ela, como já foi dito, que muitas vezes emerge como pedra-de-toque na forma de aparecimento, de organização e no desenrolar de certos fenômenos violentos. É o caso não apenas do "arrastão" mas também do grupo de moradores que, ao se preparar para linchar um suspeito, resolve telefonar para as equipes de reportagem para que registrem a cena. Não há aqui anamnese. ${ }^{12}$ Há, isto sim, a dizimação do coletivo, na perpetuação sádica e traumática da violência - sígnica e real - a deixar as marcas da destruição no visível, esta que, ao se inscrever na imagerie, o faz como liquidação última de todos os vestígios. Não é obviamente por obra do acaso que também se nota a crescente importância dos media na construção da imagem da criminalidade, das gangues de jovens e de inúmeros microcosmos que suspeitamente se incluem na categoria dos "excluídos".

Michel de Certeau disse certa vez que, depois de episódios como os bombardeios ao Vietnã, tornava-se "derrisório falar da violência". Paul Virilio passou quinze anos de sua vida viajando de barco, pelas costas da Europa, registrando em fotografias os vestígios deixados pelos alemães durante a ocupação. Hans Magnus Enzensberger exorciza em alguns de seus textos recentes a dolorosa contaminação que os ce- 
nários da guerra - a passada e a presente - exercem sobre seu discurso.

Há algo em comum entre esses homens e entre as reflexões que elaboram. A análise da violência contemporânea - e o olhar que dela emerge - é também uma análise crítica, compreendida aqui na mesma direção teorizada por Virilio (1993) em sua noção de "espaço crítico" construto que chega a uma situação limítrofe, a um estado de crise potencial - ou naquela de Arthur Kroker e David Cook (1991) ao definirem a situação atual da teoria como sendo a de um "lugar de pânico". O déjà-vu que emerge das manifestações de violência contemporâneas provém desta zona limítrofe, deste estressamento constante e pulverizado.

Ao analisar a entrada das sociedades contemporâneas na "videosfera", sucedânea da era audiovisual, Debray questiona-se sobre as expectativas que se tem, hoje, em relação às imagens: "Diz-se que 'entramos na civilização da imagem'. Estranha amnésia. O culto das imagens fabricadas pela mão do homem tem, pelo menos, 10.000 anos. (...) É verossímil que tal poder das imagens foi declinando no decorrer dos tempos e somos talvez nós, na era da televisão, quem acredita menos nessa força. No fundo, desconfiamos cada vez mais de nossas imagens, sejam elas eletrônicas ou não. Entramos na era da suspeição" (Debray, 1993:12).

A tendência a converter e perceber o mundo a partir de signos visuais não leva, de fato, à defesa incondicional de uma civilização das imagens. Estas, afinal, já foram dessacralizadas. O equívoco de Debray é supor que o tipo de relação que se estabelece com as imagens se sustenta em sua suposta "fidedignidade". Não há mais fundamento para esta expectativa. É o próprio corte entre real e ficcional, entre fato e representação que foi redimensionado. O "contrato de visibilidade" estabelecido com os media não passa pela veracidade mas, ao que tudo indica, pela intensidade. A "imagologia" é desbancada pela "sensologia".

Compartilhamos da concepção de Fredric Jameson (1995) de que o visual está assentado no arrebatamento, na fascinação emocional, e de que a tendência à visualidade é cada vez mais abrangente: "Nossa sociedade começou a nos apresentar o mundo - agora, em grande parte, um conjunto de produtos de nossa própria criação - exatamente como um corpo, que se pode possuir com os olhos e de que se podem colecionar as imagens" (Jameson, 1995:1).

As imagens que ainda nos chocam parecem ser aquelas que foram "surpreendidas", no decorrer de seu regis- tro, pela ocorrência de atos violentos. É o caso da filmagem (amadora) do linchamento de Matupá, é o registro ao vivo de suicídios - imagem que se tornou nacionalmente emblemática ao ser acompanhada e divulgada, passo a passo, pelo extinto telejornal "Aqui Agora" -, é o famoso caso do registro (também amador) do espancamento de Rodney King por policiais de Los Angeles, que desencadeou, após a divulgação das cenas e, em especial, da sentença dada aos acusados, uma explosão de revolta e destruição na cidade.

A apreensão da violência através de imagens, se não escapa de uma lógica da sedução e do arrebatamento, confere curiosa atribuição ao nosso "estoque" imagético. Cada peça adquirida perde imediatamente seu peso ou valor individual quando é inserida na "coleção". Não costumamos hierarquizar com muita facilidade as "imagens da violência". Parece ser mais comum atribuir-se a estas imagens um valor relacional, como se cada uma fosse, na verdade, a parte de um quebra-cabeças, a fração de um mosaico que, a despeito de sua capacidade constante de aglutinação e reestruturação, de seu fracionamento, apresenta-se como unidade.

Apesar de seu caráter polissêmico, as imagens de violência têm contribuído, em alguns casos, para a construção de uma nomenclatura unívoca ou com conotação universalista da violência contemporânea, englobando a esta temática visões de mundo, discursos e comportamentos extremamente diversificados. Estes, por sua vez, não se caracterizam, necessariamente, pela remissão seja a esta pluralidade, seja a este fundamento comum.

A crescente propagação de imagens da violência e a valoração que se atribui a esta violência visibilizada, reforçam, segundo nossa hipótese, uma dilatação do conceito. O tema da violência encontra-se em situação de promiscuidade com a intensa visibilização dos fenômenos de violência e com a imagem abstrata da violência que se constrói a partir deste processo.

Por outro lado, os diversos fenômenos e abordagens teóricas, incluídos involuntariamente em uma mesma alcunha, são por vezes antagônicos ou excludentes. Cada qual tende a criar sua zona de condensação, o seu buraco negro. Referimo-nos aqui ao caráter monolítico de determinados discursos genéricos, por exemplo, a associação taxativa entre (aumento da) pobreza, criminalidade e violência. Também consideramos o poder de atração exercido sobre os discursos de análise da violência por fenômenos de violência ostensivamente visibilizada. 


\section{LINGUAGEM DA VIOLÊNCIA E VIOLÊNCIA MEDIÁTICA}

A noção de "linguagem da violência" reúne ou contempla algumas das dimensões da violência como ato social, qual sejam, a violência como agregador comum reunindo circunstancialmente indivíduos e grupos que, em sua prática, vêem nela fator decisivo e partilhado de coesão, união e ação grupal -; a violência fundante - base originária da constituição da ação e da interação social -; e a violência como vetor estruturante - que define e conduz a conformação e a característica interna de práticas, hábitos, percepções e interações.

Cientes das implicações e desdobramentos de tais noções na literatura de fundamento sociológico, utilizamolas de forma basicamente ilustrativa e restringimos sua aplicação ao campo analítico da comunicação social. O recorte que adotamos, portanto, leva em conta a existência destes níveis, mas não os considera mutuamente excludentes nem lhes atribui caráter totalizante. Afinal, cada um deles pode e certamente estará mixado em seu acontecer simbólico, cotidiano e social.

Consideramos, ademais, que, ao se falar de uma "violência mediática", esteja suficientemente claro que a violência é aqui compreendida tanto como manifestação concreta, direta e ostensiva na vida cotidiana - implicando constrangimentos físicos, morais, no uso da força, na coação, na violação da integridade física e psíquica -, quanto em sua dimensão subjetiva, indireta e, inclusive, no tocante à sua mediatização. Na interseção entre o concreto e o simbólico, a violência manifesta-se como produção e linguagem estética, como forma de ser, de se comunicar, de vivenciar, de apreender e interpretar o mundo.

Nas palavras do psicanalista Contardo Calligaris (1993), a crise de "filiação" brasileira permite que atos pretensamente simbólicos tornem-se reais, ultrapassando, em sua execução, o sentido estrito de meio para a obtenção de interesses e materializando um sentimento difuso de "vingança". Assim, ele comenta o que seria, a seus olhos, uma das peculiaridades da criminalidade brasileira: "É como se no roubo e no assalto a questão não se resumisse na tentativa de se apoderar de um bem: subtraí-lo a um outro presente, privar o outro em presença parece mais importante do que se apoderar do bem. (...) Assaltando, o que importa não é tanto se apoderar do bem do outro, quanto - no instante do assalto - escravizá-lo segundo o projeto do colonizador. Roubar em ausência é sem efeito, pois é do outro que precisa se apoderar, como se o delinqüente esperasse sua dignidade de sujeito do poder afirmado de declarar ao assaltado: "Non habeas corpus" (Calligaris, 1993:120-1).

No universo da comunicação generalizada, a experimentação concreta da violência encontra o outro lado da moeda na superexposição brutal aos mais diversos níveis de violência sígnica. Analisando a violência contemporânea, Chesnais (1982) vale-se do contraponto "lei da força/força da lei" para argumentar que a violência é a única lei das sociedades sem lei. A linguagem da violência, nos termos da simbiose media/sociedade, sugere mais exatamente uma ruptura de "laços", como se eles perdessem seu valor simbólico, sua função de integração e identidade reconhecida e partilhada. Pensamos, neste caso, nos abalos sofridos em termos da vivência corpórea, da relação com o "outro", dos vínculos coletivos, territoriais, políticos. Na linguagem mediática, a coesão, a estruturação e ordenação de um mundo que parece desintegrar-se, oferecem, como alternativa, um vínculo imaterial, uma coesão apenas suposta, credível, mas, de fato, frágil em seu valor simbólico.

Uma das peculiaridades da violência contemporânea é sua excessiva visualização, que nos informa do mundo através do "ouvir ver" e, ainda, aquela que se dá a ver, violência instrumentalizada, violência publicitária. É curioso notar que o círculo mediático, mitificando a molecularização, tende a atribuir-lhe um peso maior na percepção do que seria o crescimento da violência contemporânea; mas não seria preciso sequer recorrer a estatísticas para atestar que, ao se enfocar a criminalidade, é a linguagem molar, quantitativamente, a mais letal.

Devemos agora acrescentar outra observação. As formas de violência analisadas neste trabalho demonstram que esta linguagem é também fascinante, seja para aqueles que a praticam diretamente, seja para parte daqueles que, mediaticamente, a experimentam. Uma combinação letal da violência como fascínio e do desejo de abolição é a união entre as "máquinas de guerra" e as "máquinas de visão". Uma das derivações mais radicais da linguagem da violência é aquela em que se propaga uma "estética do desaparecimento" que, literalmente, só nos deixa como alternativa de investigação uma arqueologia dos vestígios, dos sinais-destroços da dizimação.

$\mathrm{Se}$, como sugere Enzensberger, aos perdedores é delegada a autodestruição, com o afastamento do capital dos "cenários de guerra", por outro lado é exatamente deste combate endógeno e autofágico, em seu decorrer ou em seus despojos, que se alimenta parte dos telejornais "es- 
pecializados", os mesmos que tendem a se utilizar de um discurso moralizador, de um tratamento de superfície quando surgem denúncias "mais sérias", que, quando comovem ou causam indignação, o fazem, muitas vezes, pela consciência tácita da dimensão do não-visto.

Retomamos, como último comentário, a condição de possibilidade que identificamos na linguagem de alguns rappers. Assumindo que foram criados na "linguagem da violência", que ela lhes conformou a vida, as relações de sociabilidade, transformam-na em recurso simbólico, desvencilhando-se do ciclo da violência como ato social. Enxergamos aqui uma possibilidade, similar à que vislumbra Paulo Giandalia ao descrever a experiência de um ex-garoto de rua que, sonhando em ser fotógrafo, comprara, em parcelas, uma câmera, registrando cenas do cotidiano que tão bem conhecia. ${ }^{13} \mathrm{Na}$ rua desde os 8 . Desde os 4. Desde os 2 anos? Caso de polícia, número de estatística, uma probabilidade. Duarte Pereira é o nome da mãe. Ele sabe do pai? Ele tem? Nenhuma certeza (...). Certeza aos 17: mudar o destino de bicho acuado, bicho morto. Comprou uma máquina fotográfica em 6 vezes de $\mathrm{R} \$ 56,00$ nas Casas Bahia. Automática, zoom 35-80mm. Podia ter sido um walkman no Mappin aos 17. Deveria ter sido um revólver calibre 32 aos 12 . Um som de 100 watts roubado aos $11 \ldots$ Poderia ter sido. Ele é Antonio Leonardo Duarte Pereira, o fotógrafo amador. Ex-garoto de rua, sobrevivente da turma que não está preso ou morreu. Porque decidiu. A certeza de que temos possibilidades.

Vemos também problemas: o envolvimento criminal de "estrelas" do gangsta rap exemplifica, em terras norte-americanas, um deles; a limitação das alternativas de "sucesso", se se pensar em termos exclusivamente econômicos, pode ser outro. A pedagogia desta linguagem, em sua dimensão molecular e naquela molar, endurecida, deve ser olhada de frente. Mesmo se, por algum tempo, o que se encontre seja uma cadeia infindável de novas perguntas. Fazê-las, conscientes da inserção de quem pergunta no quadro sobre o qual indaga, pode ser um primeiro passo.

\section{NOTAS}

E-mail da autora: rrocha@usp.br

Este artigo contém resultados parciais da tese de doutoramento Estética da violência: por uma arqueologia dos vestígios, que contou com o financiamento de CNPq e Fapesp.

1. Embora esta análise tenha enfatizado o cenário metropolitano da atualidade, acreditamos que as reflexões propostas, com as relativizações pertinentes, possam ser aplicadas a outras situações não enfocadas aqui.
2. O autor comenta sua compreensão dos estudos etnográficos relacionando-os com a "teoria da ação" de Pierre Bourdieu.

3. A autora analisa a violência simbólica e física nas banlieues.

4. A relação que, neste sentido, se estabelece entre consumo e criminalidade merece um estudo à parte, estando neste momento apenas esboçado. Pretendemos retomar esta linha analítica em pesquisas futuras, valendo-nos, entre outras, da contribuição de Raymond Williams, particularmente em sua conceituação da cultura como um "sistema de significações realizado" (Williams, 1992:206). Outra dimensão é apontada por Borelli (1995), que propõe uma interessante aplicação da proposição de Williams acerca das "estruturas de sentimento" presentes nas relações culturais

5. Compreendida tanto como imaginário composto de representações imagéticas, quanto como o próprio estoque imagético, a coleção de imagens, de representações ou, indo mais além, como conjunto de simulações que atestam rupturas com o referente. Brissac Peixoto (1987) refere-se à imagerie como sendo parte de um processo de ficcionalização imagética do real, como conversão do real em paisagem, em figuras de ficção: "conversão de todas as coisas num cinematismo de imagens espectrais" (Brissac Peixoto, 1987:7).

6. Em Cidade de Deus, zona oeste da cidade do Rio. Nesse mesmo local, um cinegrafista amador registrou cena de violência policial, divulgada em redes de tevê em abril de 97

7. "Basicamente, insisto na necessidade de uma perspectiva que, separando analiticamente a crise institucional da organização da criminalidade, torne perceptível a singularidade da atual configuração desta última e sua importância fundamental no quadro da vida urbana contemporânea" (Machado da Silva, 1994:157).

8. Imiscuem-se, nesta definição de força, a posse ou controle de capital financeiro e de armamentos.

9. Para uma análise do gangsta rap, ver Kitwana (1994).

10. Ver, a este respeito, Wieviorka (1996).

11. Neste filme um maníaco atira de trás de uma tela de drive-in, que exibia um filme de terror.

12. Segundo Lyotard (1996:219), na anamnese o "advir advém como revir".

13. Sobre a experiência deste garoto e para se conhecerem alguns resultados de pesquisa inédita desenvolvida pela Faculdade de Saúde Pública da USP sobre menores de rua e seus familiares consultar a Folha de S.Paulo (caderno "São Paulo") de 19 de outubro de 1997.

\section{REFERÊNCIAS BIBLIOGRÁFICAS}

BORELLI, S.H.S "Gêneros ficcionais: materialidade, cotidiano, imaginário". In: SOUSA, M.W. (org.). Sujeito, o lado oculto do receptor. São Paulo, Brasiliense, 1995, p.71-85.

BRISSAC PEIXOTO, N. Cenários em ruínas. A realidade imaginária contemporânea. São Paulo, Brasiliense, 1987.

BURKE, P. Cultura popular na idade moderna. São Paulo, Companhia das Letras, 1989.

CALLIGARIS, C. "Marginalidade e criminalidade". In: Hello Brasil! Notas de um psicanalista europeu viajando ao Brasil. São Paulo, Escuta, 1993, p.109-121.

CHESNAIS, J.C. Histoire de la violence. Paris, Robert Lafond, 1982.

DE CERTEAU, M. "A linguagem da violência”. In: A cultura no plural. Campinas, Papirus, 1995, p.87-97.

DEBRAY, R. O Estado sedutor. As revoluções midiológicas do poder. Petrópolis, Vozes, 1993.

ENZENSBERGER, H.M. Guerra civil. São Paulo, Companhia das Letras, 1995.

FREIRE COSTA, J. "O medo social". Veja 25 anos: reflexóes para o futuro. São Paulo, Abril, 1993, p.83-89.

GIRARD, R. A violência e o sagrado. São Paulo, Paz e Terra/Unesp, 1990.

JAMESON, F. "Introdução". In: As marcas do visível. Rio de Janeiro, Graal, 1995, p.1-6.

KITWANA, B. The rap on gangsta rap. Who run it?: Gangsta rap and visions of black violence. Chicago, Third World Press, 1994.

KROKER, A. e COOK, D. The postmodern scene: excremental culture and hyperaesthesis. Montréal, New World Perspectives, 1991. 
LYOTARD, J.F. Moralidades pós-modernas. Campinas, Papirus, 1996.

MACHADO DA SILVA, L.A. "Violência e sociabilidade: tendências da atual conjuntura urbana no Brasil". In: RIBEIRO, L.C.Q. e SANTOS JÚNIOR, O.A. (orgs.). Globalização, fragmentação e reforma urbana: o futuro das cidades brasileiras na crise. Rio de Janeiro, Civilização Brasileira, 1994, p.147-168.

ROCHA, R.L. de M. Estética da violência. Por uma arqueologia dos vestígios. Tese de doutoramento. São Paulo, Escola de Comunicações e Artes da Universidade de São Paulo, 1998.

SILVA, H.R. e MILITO, C. Vozes do meio fio. Rio de Janeiro, Relume-Dumará, 1995.

VENTURA, Z. “A sucessão". Veja 25 anos: reflexões para o futuro. São Paulo, Abril, 1993, p.83-89.
. Cidade partida. São Paulo, Companhia das Letras, 1994.

VIRILIO, P. O espaço crítico. Rio de Janeiro, Editora 34, 1993.

WACQUANT, L. "Violence, corps et science: remarques transatlantiques" (entrevista). Prétentaine, no 5 ("Philosophie et postmodernité"), maio de 1996 , p.211-221.

WIEVIORKA, M. "Violence, culture and democracy: a european perspective". Public Culture, no 8. Chicago, Chicago University Press, 1996, p.329-354.

WILliAMS, R. Cultura. São Paulo, Paz e Terra, 1992.

WITTNER, L. "De l'image de violence à la violence de l'image". Les Annales de la Recherche Urbaine, $\mathrm{n}^{\circ} 54$ ("Violence dans les villes"). Paris, Ministère de l'Equipement, du Logement et des Transports, março de 1992, p.53-59.

ZALUAR, A. Condomínio do diabo. Rio de Janeiro, Revan/Ed. UFRJ, 1994. 